\title{
Correlation of Ghrelin and Obestatin with Waist Circumference in Central Obese Men
}

\author{
Widya Kurniawati ${ }^{1,2^{*}}$, Marsetio Donosepoetro ${ }^{4 *}$, Andi Wijaya ${ }^{3^{*}}$
}

\begin{abstract}
${ }^{1}$ Post Graduate Program in Clinical Biochemistry, Hasanuddin University, Jl. Perintis Kemerdekaan Km. 10, Makassar, Indonesia ${ }^{2}$ Prodia Clinical Laboratory, Jl. Bogowonto 14, Surabaya, Indonesia ${ }^{3}$ Faculty of Medicine, Airlangga University, Jl. Mayjen Prof. Dr. Moestopo No. 47, Surabaya, Indonesia ${ }^{4}$ Prodia Clinical Laboratory, Jl.Cisangkuy No. 2, Bandung, Indonesia "Correspondence: widya.kurniawati@prodia.co.id
\end{abstract}

\section{Abstract}

ACKGROUND: Central obesity is known as the cause of many metabolic disorders called Metabolic Syndrome. Accumulation of adipocytes in central obesity increases production of cytokines proinflammation $(1,2)$. Free fatty acid increases in obesity that drives atherogenic dyslipidemia and insulin resistance (3). IDF 2005 states that waist circumference (WC) is regarded as the simple criteria of obesity. (4). Energy imbalance lasting for a long period is a determinant factor for obesity, e.g. when energy intake is greater than energy expenditure. The brain and gastrointestinal tract work together to maintain this system. Ghrelin and Obestatin are two gut hormones that work in different ways to keep the energy balance. Ghrelin increases appetite but Obestatin decreases it. The two hormones play an important role in maintaining the dynamic equilibrium of energy balance. This study was aimed to determine correlation of Ghrelin and Obestatin with WC in central obese men.

METHODS: This was a cross sectional study involving 53 central obese men. Based on IDF 2005 central obesity is most easily measured by waist circumference using the guidelines ethnic group (not country of residence) specific. We used South Asia ethnic which including
Chinese, Malay and Asian Indian population as criteria for this study, that was $W C>90 \mathrm{~cm}$, aged $20-60$ years. Subjects who had smoking habit, any infectious disease, and ACS were excluded from the study. No restriction was applied on the kind of meals the subjects were having or activities they were doing. The correlation of waist circumference with ghrelin and obestatin was assessed with a significance level of $95 \%(\alpha=0,05)$.

RESULTS: Patient's age was 40,9623 \pm 7,9080 year, waist circumferences was $102.1981 \pm 10,2696 \mathrm{~cm}$, weight was $85,8679 \pm 16,5475 \mathrm{~kg}$, height was $168,8066 \pm 6,3535$ $\mathrm{cm}$, BMI was $29.9723 \pm 2,4937 \mathrm{~kg} / \mathrm{m} 2$. Concentration of Ghrelin were 0.70 - $13.72 \mathrm{ng} / \mathrm{mL}$, and Obestatin 16.66 $148.84 \mathrm{pg} / \mathrm{mL}$. Pearson correlation showed that Ghrelin $(\mathrm{r}=-0.1114, \mathrm{p}=0.4271)$ and Obestatin $(\mathrm{r}=-0.1781, \mathrm{p}$ $=0.2020$ ) had no significant correlation with WC. But in patients $W C \geq 120 \mathrm{~cm}$ had significant negative correlation with Obestatin $(r=-0.375, p=0.049)$.

CONCLUSIONS: There was no significant correlation of Ghrelin and Obestatin with WC in obese men. However, there was a negative correlation tendency found in patients with greater $\mathrm{WC}(\geq 102 \mathrm{~cm})$.

KEYWORDS: Obesity, Ghrelin, Obestatin, Waist Circumference (WC).

Indones Biomed J 2011 ; 3 (2) : 133-137 


\section{Introduction}

Obesity has become common among the world's population and it has started to replace under nutrition and infectious diseases as the most significant contributor to health problem $(5,6)$. Central obesity and metabolic syndrome can not be separated. Accumulation of fat in the body that occurs in central obesity leads to several diseases such as diabetes mellitus, insulin resistance, atherogenic dyslipidemia and inflammation, which are collectively known as metabolic syndrome $(5,6)$. Simple criteria for central obesity use WC measurement according to the criteria of IDF 2005. (4).

Body fat storage correlates with obesity, but it is not merely caused by bad diet habit, instead it is the result of the combination of genetic susceptibility, high intake of highenergy foods, and decreased requirements for physical activity in modern society $(7,8)$. The gastrointestinal tract plays an important role in regulation of energy homeostasis in the body through ingestion, absorption and assimilation of nutrients contained in the food $(7,8,9)$. The gastrointestinal tract consists of endocrine cells that produce some hormones useful for regulation of secretion of enzymes and other mechanisms of food processing. These hormones give signals to the brain to process energy homeostasis $(10,11)$.

The neurotransmitters that are responsible for increasing the appetite are neuropeptide Y (NPY) and Agouti Related Peptide (AgRP), while the neurotransmitter responsible for reducing the appetite is proopiomelanocortin (POMC) that produces melanocyte stimulating hormone $(\alpha-\mathrm{MSH})(12,13)$. Insulin and Leptin inhibit NPY and AgRP and stimulate POMC to produce $\alpha-\mathrm{MSH}$, in order to decrease the appetite $(12,13)$. Other hormone, named Ghrelin increases the appetite by stimulating NPY and AgRP through growth hormone secretagogue receptor (GHSR) $(14,15,16)$. Obestatin is expressed from the same gene as Ghrelin. It binds to a G protein-coupled receptor (GPR39) against Ghrelin to suppress the appetite $(8,17)$.

In 1999, Ghrelin was found as a gastrointestinal hormone that stimulated production of growth factor in mice. On the other hand, the mice studied became fat due to the continuous injection of Ghrelin. In fact, Ghrelin increased appetite of the mice and decreased energy expenditure. So the samples became obese (18). This finding has attracted many other studies done on the correlation of Ghrelin with obesity and some other conditions such as diabetes mellitus, inflammation and metabolic syndrome.
Ghrelin has some biological functions mainly in stimulation of growth hormone and appetite and carbohydrate metabolism (19). Secretion of Ghrelin increases with the decrease of body weight, restriction of calorie intake, and increase of insulin that causes hypoglycemic effect $(20,21)$. In in vitro studies, Zhang et al. in 2005 showed that Ghrelin inhibited adipogenesis through PPAR (peroxisome proliferator-activator receptor) (21).

Tschoop and Zhang found that Obestatin has the opposite effect as Ghrelin in normal condition. In normal condition Ghrelin and Obestatin are on a dynamic equilibirium. So, if the role of Ghrelin is disclosed, we can predict the role of Obestatin $(8,21)$. Our hypothesis is there is correlation between Ghrelin and Obestatin with waist circumference in the obese men.

\section{Methods}

\section{SUBJECTS}

This was a cross-sectional study involving 53 central obese men, defined by waist circumference $>90 \mathrm{~cm}$. Based on IDF 2005 , central obesity is most easily measured by waist circumference using the guidelines ethnic group specific, but not country of residence. We used South Asia ethnic which including Chinese, Malay and Asian Indian population as criteria for this study. WC was used to define central obesity because it's simple, reliable, and correlated well with abdominal fat content irrespective of BMI (Body Mass Index). Subjects recruitment and data collection were done in 2007 in Surabaya, and all subjects were required to state their willingness to follow the study protocol by signing an informed consent. The study protocol has been approved by The Health Research Ethics Committee of The Faculty of Medicine, Hasanuddin University of Makassar. Subjects with smoking habit, infectious disease, and Acute Coronary Syndrome (ACS) were excluded from the study. This study did not make any restriction on the meals or activities of the study subjects.

\section{ASSAY OF BIOCHEMICAL MARKERS}

Biochemical markers were measured using Ghrelin (human) EIA kit (Phoenix Pharmaceuticals, Inc., Saint Joseph, USA) and Obestatin (Human, Monkey) RIA kit (Phoenix Pharmaceuticals, Inc., Saint Joseph, USA). Briefly, fasting blood samples were collected in the morning between 07.00 until $10.00 \mathrm{am}$. Serum was separated from the whole blood after centrifugation and immediately kept at $-70^{\circ} \mathrm{C}$. 


\section{STATISTICAL ANALYSIS}

SPSS for Windows ver. 11.5 was used for all statistical and graphical analyses. General analysis of data was done by univariate analysis to determine the minimum and maximum value, average, and standard deviation. Independent and dependent variables were analyzed by bivariate and partial Pearson Correlation. One Way Annova was used to analyze the difference between Ghrelin and Obestatin in the obese subjects.

\section{Results}

Characteristic of samples examined show in table 1 and 2 . Result of Ghrelin and Obestatin were in the wide range, because this study wasnot use any stricted food intake to the patients. The patients were fasting before blood sampling, but there were no rules in the food variation intake for patient in the several days before blood sampling. Ghrelin and Obestatin were gastrointestinal hormones that might be different amount in every person depends on their food intake. They were Indonesian men average 20-60 years old. Group ethics population of the patients were Chinese and Malay only. Data of subject characteristics were distributed normally so we used Mean datas, but Ghrelin and Obestatin didn't distributed normally that's why we use median in the statistics.

The data of WC and BMI separate in two group based on mean value. WC cut point was $102 \mathrm{~cm}$ There were 28 men with $\mathrm{WC}<102 \mathrm{~cm}$ and there were 23 men with $\mathrm{WC} \geq 102 \mathrm{~cm}$. BMI cut point was $30 \mathrm{~kg} / \mathrm{m}^{2}$. There were 34 men with BMI $<30 \mathrm{~kg} / \mathrm{m}^{2}$ and there were 19 men with BMI $\geq 30 \mathrm{~kg} / \mathrm{m}^{2}$. In this study used WC as criteria of central obesity but BMI was still analyze to compare the result.

Table 1. Subjects' characteristics

\begin{tabular}{lcrr}
\hline Variabel & Mean \pm SD & Min & Max \\
\hline N & 53 & & \\
Age & $40.9623 \pm 7.9080$ & 29 & 59 \\
WC $(\mathrm{cm})$ & $102.1981 \pm 10.2696$ & 90 & 132 \\
Weight $(\mathrm{kg})$ & $85.8679 \pm 16.5475$ & 64 & 140 \\
Height $(\mathrm{cm})$ & $168.8066 \pm 6.3535$ & 158 & 184 \\
BMl $\left(\mathrm{kg} / \mathrm{m}^{2}\right)$ & $29.9723 \pm 2.4937$ & 23.78 & 41.35 \\
\hline
\end{tabular}

$W C=$ Waist Circumference $(\mathrm{cm}), \mathrm{BMI}=$ Body Mass Index $\left(\mathrm{Kg} / \mathrm{m}^{2}\right)$.

Table 2. Ghrelin and Obestatin Level in Central Obese Men

\begin{tabular}{lrrr}
\hline Variabel & Median & Min & Max \\
\hline Ghrelin $(\mathrm{ng} / \mathrm{mL})$ & 1.95 & 0.70 & 13.72 \\
Obestatin $(\mathrm{pg} / \mathrm{mL})$ & 38.86 & 16.66 & 148.84 \\
\hline
\end{tabular}


Table 3 shows that Ghrelin $(r=-0.1114, p=0.4271)$ and Obestatin $(r=-0.1781, p=0.2020)$ had no significant correlation with WC. But in patients WC $\geq 120 \mathrm{~cm}$ had significant negative correlation with Obestatin $(r=-0.375$, $p=0.049)$. There were significant negative correlation between BMI and Ghrelin, but neither Obestatin. Ghrelin and Obestatin had negative tendency correlation with BMI.

\section{Table 3. Correlation between Ghrelin and Obestatin with WC and BMI in central obese patients}

\begin{tabular}{lllll}
\hline Variabel & \multicolumn{2}{c}{ Ghrelin } & \multicolumn{2}{c}{ Obestatin } \\
& $\mathbf{r}$ & $\mathbf{p}$ & $\mathbf{r}$ & $\mathbf{p}$ \\
\hline Waist circumference & -0.1114 & 0.4271 & -0.1781 & 0.202 \\
WC $<102$ & 0.005 & 0.98 & -0.375 & $0.049^{*}$ \\
WC $\geq 102$ & -0.087 & 0.68 & -0.125 & 0.551 \\
Body Mass Index & -0.283 & $0.04^{*}$ & -0.126 & 0.369 \\
BMI < 30 & -0.225 & 0.201 & -0.077 & 0.667 \\
BMI $\geq 30$ & -0.16 & 0.95 & -0.135 & 0.58 \\
\hline
\end{tabular}

Correlation is significant at the 0.05 level

\section{Discussion}

Although this study showed no significant correlation between Ghrelin and Obestatin, the negative tendency found in this study had confirmed the results of some studies done earlier. Rosicka et al. proved a significantly lower serum Ghrelin level in the group of central obese patients in comparison with the control group (22). In this study there was no food intake restriction, so we found the different result with study before. This study has confirmed that Ghrelin in subjects with WC $\geq 100$ $\mathrm{cm}$ had a negative correlation. It means that the level of Ghrelin gets lower when a subject has become more obese. The tendency of Obestatin in this study agrees with results of a recent study on Obestatin in overweight and obese patients, in which concentrations of obestatin was found decreased in overweight and obese patients (23) .

Zhang et al. (2007) mentioned that Ghrelin and Obestatin had an inverse relationship with BMI and WC (24). Energy imbalance in the body will trigger the occurrence of obesity, including appetite regulation, controlled by Ghrelin and Obestatin. Ghrelin secretion will increase with the decrease of body weight, caloric intake restriction, and the increase of insulin level that causes hypoglycemic effect. Another further study is recommended to carry out with restriction made on nutrition and activities of the subjects to compare with the present results $(22,24)$. Recent studies have indicated that ghrelin levels in systemic circulation reflect mainly nutritional status and are predominantly involved in the regulation of energy homeostasis. Thus the states associated with malnutrition are accompanied by an increase of serum ghrelin levels (25), whereas overfeeding is accompanied by decrease of serum ghrelin levels (26)

A study by Levin et al. has found that the decrease in body fat content caused an increase in the level of Ghrelin. As it is expressed from the same gene, it is suggested that Obestatin might have the similar pattern (27). Obesity correlates with increased body weight and accumulation of adipose tissues (7). It means that obesity may decrease secretion of Ghrelin and Obestatin. This study suggested that Ghrelin and Obestatin had a negative correlation with obesity (characterized by WC $>102 \mathrm{~cm}$ ). We therefore can conclude that greater WC measurement is associated with lower Ghrelin and Obestatin levels.

Obesity can be caused by imbalance of energy homeostasis. The gastrointestinal tract consists of endocrine cells that produce some useful hormones that 
regulate secretion of enzymes and other mechanisms of food processing (11). These hormones give many signals to the brain to process energy homeostasis (10). Ghrelin and Obestatin are hormones that are produced by the gastrointestinal tract and are involved in energy homeostasis. Patient with bigger waistline and overweight patients (BMI $>25 \mathrm{~kg} / \mathrm{m}^{2}$ ), however, production of these hormones is decreased causing disruption of the dynamic equilibrium between the two.

\section{Conclusion}

Results of this study showed no significant correlation of Ghrelin and Obestatin with WC in obese men. However, there was a negative correlation tendency found in patients with greater $\mathrm{WC}(\geq 102 \mathrm{~cm})$.

\section{Acknowledgements:}

We thank to Andi Wijaya and Marsetio Donoseputro and The Prodia Laboratory for supporting this research.

\section{References:}

1. Wellen KE, Gokhan SH. Obesity Induced Inflammation Changes in Adipose Tissue. J. Clin. Invest 2003; 112: 1785-7.

2. Wellen KE, Hotamisligil GS. Inflammation, Stress, and Diabetes, J. Clin. Invest 2005; 115 : 1111-9.

3. Gil-Campos M, Canete R, Gil A. Hormones Regulating Lipid Metabolism and Plasma Lipids in Childhood Obesity. Int J Obes Relat Metab Disord 2004; 28: S75-80.

4. International Diabetes Federation 2005. The IDF Consensus Worldwide Definition of the Metabolic Syndrome (on line). www.idf.org.

5. Kopelman PG. Obesity as a Medical Problem. Nature 2000; 404: 635-43.

6. Allison DB, Saunders SE. Obesity in North America. Med Clin North Am 2000; 84: 302-25.

7. Wood SC, Seeley RJ. Understanding the Physiology of Obesity: Review of Recent Developments in Obesity Research. Int J Obese Relat Metab Disord 2002; 26: Suppl 4:S8-10.

8. Tschop M, Nogueiras R. Separation of Conjoined Hormones Yields Appetite Rivals, Science 2005; 310: 985-6.

9. Drucker DJ. 2007, The Role of Gut Hormones in Glucose Homeostasis, J. Clin. Invest 2007; 117: 24-32.
10. Dufour RD. Gastrointestinal Function and Digestive Disease, in Textbook of Clinical Chemistry (Theory, Analysis, Corelation) 2003, Kaplan LA, Pesce AJ, Kazmierczak SC, USA, Mosbi Inc, 4th ed, page 549-66.

11. Merchant JL. Tales from the Crypts : Regulatory Peptides and Cytokines in Gastrointestinal Homeostasis and Disease. J Clin Invest 2007; 117: 6-12.

12. Korner J, Leibel RL. To Eat or Not To Eat-How The Gut Talks to The Brain. New Eng J Med 2003; 349: 926-8.

13. Gale S, Castracane VD, Mantzoros CS. Energy Hemostasis, Obesity, Eating Disorder: RecentAdvances in Endocrinology. J. Nutr 2003; 134: 295-8.

14. Shintani M, OgawaY, Ebihara K, Aizawa-Abe M, Miyanaga F, Takaya K, et al. Ghrelin, and Endogenous Growth Hormone Secretagogue, is A Novel Orexigenic Peptide That Antagonized Leptin Action Through The Activation of Hypothalamic Neuropeptide Y/Y1 Receptor Pathway. Diabetes 2001; 50: 227-32.

15. Hosoda H, Kojima M, Kangawa K. Ghrelin and The Regulation of Food Intake and Energy Balance. Molecular Intervention 2002; 2: 494-503.

16. Cummings DE, Overduin J. Gastrointestinal Regulation of Food Intake. J Clin Invest 2007; 117: 13-23.

17. Zhang W, Zhao L, Lin TR, Chai B, Fan Y, Gantz I, et al. Inhibition of Adipogenesis by Ghrelin. Molecular Biology of the Cell 2004; 15: 2484-91.

18. Kojima M, Hosada H, Date Y, Nakazato M, Matsuo H, Kangawa K. Ghrelin is a Growth Hormone Releasing Acylated Peptide from Stomach. Nature 1999; 402: 656-60.

19. Adrian T. Importance of Gut Hormones in Gastrointestinal, Metabolic and Malignant Disease. Curr Opin Endocrin Diab 2005; 12 : 80-8.

20. Cummings DE, Overduin J, Schubert KEF. Roles for Ghrelin in the Regulation of Appetite and Body Weight. Curr Opin Endocrinol Diab 2005; 12: 72-9.

21. Zhang JV, Ren P, Kretchmer OA, Wei Luo, Rouch R, Klein C, et al. Obestatin, a Peptide Encoded by the Ghrelin Gene, Opposes Ghrelin's Effects on Food Intake. Science 2005; 310: 996-9.

22. Rosická M, Krsek M, Matoulek M, Jarkovská Z, Marek J, Justová V, et al. Serum Ghrelin Levels in Obese Patients : the Relationship to Serum Leptin Levels and Soluble Leptin Receptors Levels. Physiol Res.2003 ; 52: 61-6.

23. Zamrazilova H, Hainer V, Sedlackova D, Papezova H, Kunesova $\mathrm{M}$, Bellisle $\mathrm{F}$, et al. Plasma Obestatin Levels in Normal Weight, Obese and Anorectic Women. Physiol Res 2008; 57 (Suppl1) : S49-55.

24. Zhang Z, Guo Z, Zheng X, Qin YW, Hu JQ, Chen SP. Circulating Preprandial Ghrelin to Obestatin Ratio is Increasing in Human Obesity. J Clin Endocrin Metab 2007; 92: 1875-80.

25. Otto B, Cuntz U, Fruehauf E. Weight Gain Decreases Elevated Plama Ghrelin Concentration of Patients with Anorexia Nervosa. Eur J. Endocrinol 2001;145: 669-73.

26. Tschop M, Smiley DL, Heiman ML. Ghrelin Induces Adiposity in Rodent. Nature 2000; 407 : 908-13.

27. Levin F, Edholm T, Schmidt PT, Gryback P, Jacobsson H, Degerblad M, et al. Ghrelin Stimulates Gastric Emptying and Hunger in Normal-Weight Humans. J. Clin Endocrinol Metab 2006; 91: 3296-302. 